\title{
Predictors of quality of life in Czech female breast cancer survivors following treatment with special interest to coping strategies
}

Jiří Jarkovský1, Kateřina Skřivanová², Klára Benešová', Lenka Šnajdrová', Jakub Gregor', , Hana Peterkováa, Marcela Bendová4, Dagmar Brančíková5, Nela Elfmarková6, Tomáš Svěrák ${ }^{6}$, Lubomíra Anderková6, Luboš Mináŕ ${ }^{4}$, Markéta Protivánková ${ }^{5}$, Jan Nedvěd ${ }^{3}$, Ladislav Dušek', Lydia Temoshok ${ }^{7}$

I'nstitute of Biostatistics and Analyses, Faculty of Medicine, Masaryk University, Brno, Czech Republic

2Department of Clinical Psychology of University Hospital Brno, Faculty of Medicine, Masaryk University, Brno, Czech Republic

${ }^{3}$ Faculty of Medicine, Masaryk University, Brno, Czech Republic

${ }^{4}$ Department of Obstetrics and Gynaecology, University Hospital Brno and Masaryk University, Brno, Czech Republic

${ }^{5}$ Department of Internal Medicine, Haematology and Oncology, University Hospital Brno and Masaryk University, Brno, Czech Republic

${ }^{6}$ Faculty of Medicine and Applied Neuroscience Research Group, Central European Institute of Technology, Masaryk University (CEITECMU), Brno, Czech Republic

־University of Maryland, Catonsville, MD, USA

\section{Summary}

Objectives: This study examined the prognostic significance of breast cancer patients' characteristics (coping strategies, BMI, age) and disease characteristics (stage of disease, relapse) with respect to quality of life (QoL) following treatment. Sample and settings: 120 breast cancer patients following treatment were recruited. Health-related QoL was assessed using the Czech version of FACT-B and SF-36; additionally, we used a life satisfaction questionnaire. Coping strategies were assessed using the SVF-78 method. In our sample of women, the average time from diagnosis to start of the study was 5.3 years. Statistical analysis: Factors influencing QoL after treatment were analysed with univariate and multivariate linear regression. Results: Overall negative strategy defined in SVF-78 (Flight tendency, Resignation and Self-accusation) was found to be associated with lower scores of most components of used QoL methods, while Resignation was found as the most negatively influencing strategy. Active problem confrontation (Situation control and Positive self-instruction) was associated with better QoL. More advanced stages and recurrence were related to a significant decrease in QoL for certain components only. Conclusion: Our findings suggest a significant predictive power of disease-related factors and of patients' characteristics including coping strategies for QoL following treatment in Czech breast cancer survivors.

Key words: breast cancer survivors - coping strategy - linear regression model - quality of life prediction - resignation

\section{Prediktory kvality života u českých pacientek po léčbě karcinomu prsu}

\section{se zaměřením na dovednosti zvládání zátěže}

\section{Souhrn}

Cíle práce: Studie hodnotí prognostický význam charakteristik pacientek s karcinomem prsu (dovednosti zvládání zátěže, $\mathrm{BMI}$, věk) a jejich onemocnění (stadium onemocnění, relaps) pro kvalitu života ( $\mathrm{Q} Q \mathrm{~L})$ po léčbě. Soubor a metody: Do studie bylo zahrnuto 120 pacientek po léčbě karcinomu prsu. Ke zdraví vztažená kvalita života byla hodnocena českou verzí FACT-B a SF-36; jako doplňujíć informace bylo použito dotazníku životní spokojenosti. Dovednosti zvládání zátěže byly hodnoceny pomocí SVF-78. Průměrná doba od diagnózy do zahájení studie byla v našem souboru žen 5,3 let. Statistická analýza: Faktory ovlivňující QoL byly hodnoceny jednorozměrnou a vícerozměrnou lineární regresí. Výsledky: Byl zjištěn vztah celkově negativní strategie definované SVF-78 (Úniková tendence, Rezignace a Sebeobviňování) s nižší hodnotou většiny komponent použitých QoL metod, přičemž Rezignace byla zjištěna jako strategie s největším negativním vlivem. Aktivní řešení problému (Kontrola situace a Pozitivní sebeinstruování) bylo spjato s lepší QoL. Pokročilejší stadia a rekurence onemocnění byly spjaty s významným poklesem některých komponent QoL. Závěr: Naše výsledky naznačují významnou prediktivní sílu charakteristik onemocnění i pacientů včetně dovedností zvládání zátěže pro QoL po léčbě u českých pacientek přeživších onemocnění karcinomem prsu. 
Klíčová slova: dovednosti zvládání zátěže - lineární regresní model - predikce kvality života - přeživší karcinom prsu - rezignace

\section{Introduction}

Improvements in the outcomes of cancer treatment and the real possibility of long-term survival have enhanced the attention paid to the quality of life (QoL) and to its monitoring in cancer patients. The QoL definition is derived from a concept that describes four areas of a fulfilling life for an individual: physical, psychological and social status, as well as spiritual aspects [1]. QoL in cancer patients is not only affected by consequences of the disease itself, but also by side effects of treatment [2]. Breast cancer patients experience both physical symptoms and psychosocial distress, which have a profound and negative impact on their QoL. In general, a patient's QoL consists of a number of domains, including physical functioning, psychosocial well-being (anxiety, depression), and social support. Individual breast cancer experience may vary, but it usually includes most of the following phases: diagnosis, primary treatment, special issues related to non-invasive breast cancer, genetic risk, recurrence, completing treatment and re-entry to normal living, survivorship, and palliation for advanced cancer [3].

Over the last few decades, incidence rates for breast cancer in women in the Czech Republic have been growing, particularly in stages I and II. Fortunately, due to early detections of tumours and improved treatment strategies, mortality rates have stabilised, and the number of breast cancer survivors is therefore growing $[4,5]$. Effects of clinical, psychological and socioeconomic characteristics and factors on the breast cancer patients' quality of life and/or survival have been widely investigated and discussed. Among clinical and sociodemographic factors, the most important include the clinical stage, the degree of depression and anxiety, fear of recurrence, comorbidities, and treatment mode [6-9]. Psychological factors also play a role in the prevention of side effects, and optimization of expectations might be a potential pathway in an effort to improve the patients' quality of life during a long-term administration of medication(s) [10]. From the socioeconomic point of view, a lower level of education, bad financial situation, unemployment and lack of psychological counselling all contribute to a deterioration in QoL [11,12].

Coping strategies may play a role in the adaptation on the disease and its treatment. Coping has been defined by Lazarus, Folkman, and their colleagues as a "person's cognitive and behavioral efforts to manage (reduce, minimize, master, or tolerate) the internal and external demands of the person-environment transaction that is appraised as taxing or exceeding the person's resources, according to this view, coping has two major functions: dealing with the problem that is causing the distress (problem-focused coping), and regu- lating emotion (emotion-focused coping)" [13]. Breast cancer patients have shown higher repression rates compared with healthy controls, possibly as a response to the threat associated with cancer diagnosis [14]. Finally, some defence mechanisms may even be indicators of lowered survival in cancer patients [15].

The objective of this study was to evaluate the predictive power of patients' characteristics (body mass index, age, coping strategies) and disease characteristics (relapse, stage of disease, comorbidities) with respect to QoL following treatment in breast cancer patients. We tested a hypothesis that both types of characteristics contributed to QoL, and that the use of active coping strategies was associated with better QoL outcomes in comparison with the use of negative coping strategies. This study focused specifically on the investigation of possible influences of QoL coping strategies on quality of life in breast cancer survivors as the first in the Czech Republic.

\section{Materials and methods}

\section{Patients and eligibility criteria}

Eligibility criteria included histologically confirmed breast cancer, age between 30 and 90 years, and a sufficient knowledge of the Czech language. 187 women with breast cancer were recruited and participated in initial interviews, and 120 of them subsequently completed health-related QoL questionnaires and the life-satisfaction questionnaire. In our sample of women, the average time from diagnosis to start of the study was 5.3 years. After having their treatment completed, the patients carried out a self-assessment of their QoL after undergoing the treatment. Patients treated at two departments of the University Hospital Brno and Masaryk University were analysed: the Department of Gynaecology and Obstetrics, and the Department of Internal Medicine - Haematology and Oncology. All patients gave their informed consent with participation in the study, and the study was approved by the institutional review board of the University Hospital Brno. Standardized in-person interviews were conducted to assess sociodemographic data. Clinical data were obtained from medical records maintained by attending oncologists. We respect a cancer survivorship as a term defined in $\mathrm{NCl}$ dictionary of cancer terms [16]: who remains alive and continues to function during and after overcoming a serious hardship or life-threatening disease. In cancer, a person is considered to be a survivor from the time of diagnosis until the end of life.

\section{Assessment of health-related quality of life and coping strategies}

After undergoing their treatment, the patients completed a self-assessment of their current status of QoL. QoL was 
assessed using the Czech research version of Functional Assessment of Cancer Therapy - Breast (FACT-B) questionnaire, Short Form 36 Health Survey (SF-36) questionnaire and Life Satisfaction Questionnaire. All of the above-mentioned questionnaires are brief and self-reporting. The FACT-B questionnaire was chosen for its specificity due to illness. The SF-36 questionnaire was validated on the Czech population. The Life Satisfaction Questionnaire also focuses on the area of sexuality, unlike other questionnaires (FACT-B and SF-36). FACT-B [17] is a questionnaire used for self-assessment specifically developed for breast cancer patients, and includes the assessment of physical, social, family, emotional and functional well-being plus other possible complaints. An authorized Czech translation of FACT-B was used for the purpose of our research; this translation was provided by the FACIT.org as the copyright holder; the internal consistency reliability based on Cronbach's alpha is 0.800 . SF-36 [18] is a survey constructed to study health-related quality of life and consists of eight health concepts: physical functioning, role limitations caused by physical health problems, role limitations caused by emotional problems, social functioning, emotional well-being, energy/fatigue, pain, and general health perceptions. A Czech translation of the SF-36 survey was used for the purpose of our research; this translation was subject to a validation, which confirmed that the Czech version of SF-36 is as effective as the original US version [19]. Scores were calculated according to the original US version. Life Satisfaction Questionnaire [20] is a tool to study satisfac-

\section{Tab. 1. Basic characteristics of patients $(N=120)$}

\begin{tabular}{|c|c|c|c|c|c|}
\hline characteristics & $\mathrm{N}$ & $\begin{array}{c}\text { median } \\
\text { (min-max) or } \%\end{array}$ & characteristics & $\mathrm{N}$ & $\begin{array}{c}\text { median } \\
(\text { min-max) or } \%\end{array}$ \\
\hline \multicolumn{3}{|l|}{ basic characteristics } & faith & 87 & $72.5 \%$ \\
\hline age & 120 & $65.0(32.0 ; 83.0)$ & \multicolumn{3}{|l|}{ anamnesis } \\
\hline BMI & 117 & $27.5(17.6 ; 39.9)$ & stress in the last 5 years & 85 & $70.8 \%$ \\
\hline children & 112 & $93.3 \%$ & psychiatric therapy & 21 & $17.5 \%$ \\
\hline smoking & 23 & $19.2 \%$ & psychological therapy & 13 & $10.8 \%$ \\
\hline alcohol abuse & 5 & $4.2 \%$ & depression & 20 & $16.7 \%$ \\
\hline age at first birth & & & use of exogenous hormones & 50 & $41.7 \%$ \\
\hline$\leq 20$ years & 27 & $24.1 \%$ & previous oncologic disease & 19 & $15.8 \%$ \\
\hline $21-30$ years & 82 & $73.2 \%$ & diabetes mellitus & 27 & $22.5 \%$ \\
\hline$>30$ years & 3 & $2.7 \%$ & dysrhythmia & 19 & $15.8 \%$ \\
\hline breast-feeding & 100 & $83.3 \%$ & vascular brain disease & 22 & $18.3 \%$ \\
\hline first menstruation $<11$ years & 11 & $9.2 \%$ & hypertension & 60 & $50.0 \%$ \\
\hline postmenopausal & 101 & $84.2 \%$ & ischemic heart disease & 17 & $14.2 \%$ \\
\hline \multicolumn{3}{|l|}{ social and demographic characteristics } & chronic obstructive pulmonary disease & 12 & $10.0 \%$ \\
\hline education & & & chronic renal insufficiency & 4 & $3.3 \%$ \\
\hline primary school (9 years) & 17 & $14.2 \%$ & thyreopathy & 21 & $17.5 \%$ \\
\hline apprentice (12 years) & 34 & $28.3 \%$ & gastroduodenal ulcer disease & 9 & $7.5 \%$ \\
\hline secondary school (13 years) & 45 & $37.5 \%$ & \multicolumn{3}{|l|}{ disease and treatment } \\
\hline college/university (16 years) & 24 & $20.0 \%$ & \multicolumn{3}{|l|}{ stage (unknown in 2 patients) } \\
\hline employment & & & $0-1$ & 45 & $38.1 \%$ \\
\hline common employee & 90 & $75.0 \%$ & II-III & 60 & $50.8 \%$ \\
\hline employee in leading position & 30 & $25.0 \%$ & IV & 13 & $11.0 \%$ \\
\hline lifestyle & & & surgery & 114 & $95.0 \%$ \\
\hline typical city & 71 & $59.2 \%$ & chemotherapy & 76 & $63.3 \%$ \\
\hline typical country & 49 & $40.8 \%$ & radiotherapy & 100 & $83.3 \%$ \\
\hline marital status & & & biological therapy & 21 & $17.5 \%$ \\
\hline single & 7 & $5.8 \%$ & hormone therapy & 98 & $81.7 \%$ \\
\hline married & 67 & $55.8 \%$ & progression (unknown in 7 patients) & 13 & $11.5 \%$ \\
\hline divorced & 23 & $19.2 \%$ & relapse (unknown in 4 patients) & 23 & $19.8 \%$ \\
\hline widowed & 23 & $19.2 \%$ & & & \\
\hline
\end{tabular}


tion with life on a nine-point scale, and contains ten dimensions of life:
1. health
2. work and career
3. financial situation
4. recreation
5. marriage and partnership
6. relationship with own children
7. own self
8. sexuality
9. friends, acquaintances, relatives
10. housing

An index of global life satisfaction is formed from the scale values. Coping strategies as a part of patient's characteristics (play down, guilt denial, distraction from situation, substitutional satisfaction, situation control, reaction control, positive self-instruction, need for social support, active avoidance, flight tendency, rumination, resignation, self-accusation) were assessed by the SVF-78 method [21]. The internal consistency in Czech standardization is sufficiently high (Cronbach's alpha varies between 0.77 and 0.94).

\section{Statistical analyses}

Standard descriptive statistics were applied in the analysis: absolute and relative frequencies were employed for categorical variables, and median supplemented by min-max range was used for continuous variables. Internal consistency reliability for the Czech version of FACT-B was tested using Cronbach's alpha. Factors influencing the QoL scores after treatment were analysed and described using the method of univariate and multivariate linear regression for which the variables were selected by stepwise procedure excluding redundant variables on the overall positive and negative coping strategy. Adjusted R-squared values and both unstandardized and standardized coefficients are reported. Standardization puts all of the variables on the same scale, thus it is possible to compare their effects on the QoL. The statistical analysis was computed using IBM SPSS Statistics for Windows, version 24 (IBM Corp., Armonk, NY, USA) regarding standard setting of the tests with $a=0.05$. Scores were evaluated according to valid recommendations. In accordance with the generally accepted recommendations, it is possible to consider a difference of at least 10 percentage points in the QoL score as clinically relevant.

\section{Results}

Women diagnosed and treated with breast cancer $(\mathrm{N}=120)$ were included in the participating centres at University Hospital Brno. Median age was 65; tab. 1 shows their overall clinical, social and demographic

\begin{tabular}{|c|c|c|c|c|}
\hline SF-36 components: explanatory variables & beta $(95 \% \mathrm{Cl})$ & stand. beta & $\mathbf{P}$ & adjust. R-sq. \\
\hline \multicolumn{5}{|l|}{ physical functioning } \\
\hline $\begin{array}{l}\text { diabetes mellitus in anamnesis } \\
\text { flight tendency (SVF 78) }\end{array}$ & $\begin{array}{c}-13.800(-25.073 ;-2.526) \\
-0.995(-1.700 ;-0.289)\end{array}$ & $\begin{array}{l}-0.242 \\
-0.279\end{array}$ & $\begin{array}{l}0.017 \\
0.006\end{array}$ & $10.9 \%$ \\
\hline \multicolumn{5}{|l|}{ role functioning - physical } \\
\hline flight tendency (SVF 78) & $-1.374(-2.306 ;-0.443)$ & -0.268 & 0.004 & $7.2 \%$ \\
\hline \multicolumn{5}{|l|}{ bodily pain } \\
\hline flight tendency & $-1.193(-1.869 ;-0.517)$ & -0.316 & $<0.001$ & $10.0 \%$ \\
\hline \multicolumn{5}{|l|}{ general health } \\
\hline resignation (SVF 78) & $-0.632(-1.007 ;-0.257)$ & -0.305 & 0.001 & $9.3 \%$ \\
\hline \multicolumn{5}{|l|}{ vitality } \\
\hline $\begin{array}{l}\text { stage IV } \\
\text { resignation (SVF 78) }\end{array}$ & $\begin{array}{c}-19.468(-30.861 ;-8.074) \\
-0.544(-0.922 ;-0.166)\end{array}$ & $\begin{array}{l}-0.326 \\
-0.274\end{array}$ & $\begin{array}{l}0.001 \\
0.005\end{array}$ & $18.2 \%$ \\
\hline \multicolumn{5}{|l|}{ social functioning } \\
\hline flight tendency (SVF 78) & $-0.917(-1.535 ;-0.299)$ & -0.270 & 0.004 & $7.3 \%$ \\
\hline \multicolumn{5}{|l|}{ role functioning - emotional } \\
\hline flight tendency & $-1.510(-2.480 ;-0.541)$ & -0.282 & 0.003 & $8.0 \%$ \\
\hline \multicolumn{5}{|l|}{ mental health } \\
\hline $\begin{array}{l}\text { stage IV } \\
\text { resignation (SVF 78) }\end{array}$ & $\begin{array}{c}-11.509(-21.100 ;-1.918) \\
-0.843(-1.161 ;-0.525)\end{array}$ & $\begin{array}{l}-0.215 \\
-0.475\end{array}$ & $\begin{array}{r}0.019 \\
<0.001\end{array}$ & $27.7 \%$ \\
\hline
\end{tabular}

Components of both SVF 78 and SF-36 questionnaires were transformed on a scale of $0-100$ 
characteristics. Factors influencing the values of QoL scores components (SF-36, Czech research version of FACT-B and Life Satisfaction Questionnaire), which were selected in multivariate regression analysis, are shown in tab. 2-4.

Flight tendency and resignation are two main coping strategies that were found to be associated with lower scores of all SF-36 components. Self-accusation was a significant predictor of bodily pain, lower vitality, emotional role functioning and in the first place lower mental health in univariate analysis. These three components are all part of overall negative strategy and highly correlated, thus only one coping strategy usually entered the final multivariate regression model. The only statistically significant clinical parameters in multivariate models were the fourth stage of the disease as a predictor of lower vitality and mental health, and diabetes mellitus as a predictor of lower physical functioning. As in SF-36 questionnaire, flight tendency and resignation are the most important coping strategies negatively influencing QoL measured by components of FACT-B questionnaire. Out of the investigated clinical factors, the fourth stage of the disease was significant multivariate factor for almost all FACT-B components. The relapse occurrence was linked to lower physical well-being and more additional concerns. Interestingly, play down as a coping strategy positively influenced social and family well-being. The score of majority LSQ (Life Satisfaction Questionnaire) components were decreased by resignation as the most influencing coping strategy. The lost of situation control made worse the satisfaction in employment and in housing. Positive self-instruction leaded to higher satisfaction with marriage and partnership. Sexuality was negatively influenced by resignation and the relapse occurrence. In addition to resignation, the perception of personality was negatively influenced by self-accusation and higher BMI. On the other hand, reaction control had a positive influence on personality and contributed to better relations with friends and relatives. Greater age was connected to decreased satisfaction with leisure time, but on the contrary, patients of greater age had higher level

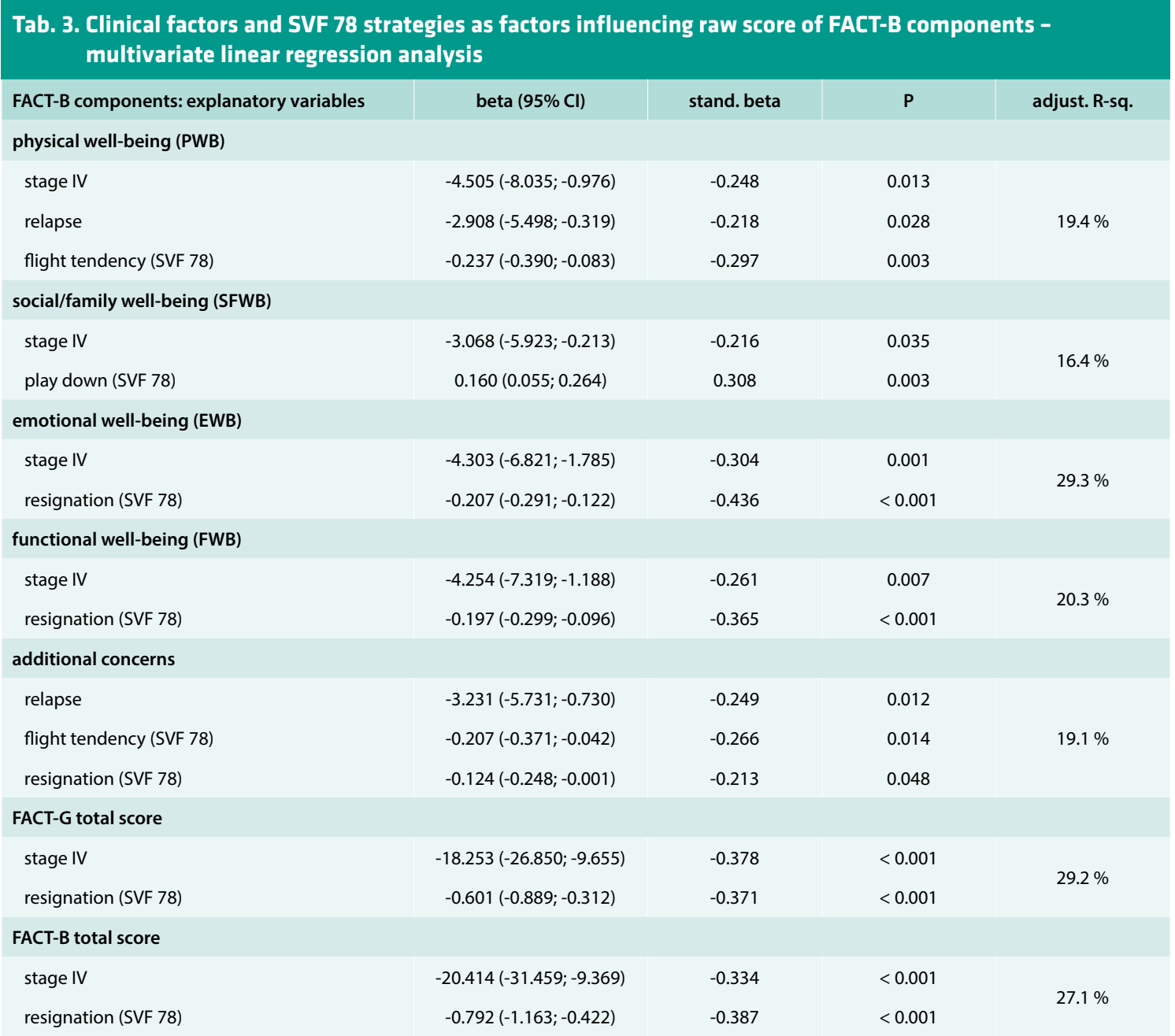

Components of SVF 78 were transformed on a scale of $0-100$ 
of satisfaction with their health conditions. The total life satisfaction was mainly influenced by the degree of resignation and reaction control.

\section{Discussion}

Patients' characteristics as predictors of QoL following treatment

Coping strategies, age and BMI

Several apparent trends have been revealed, such as the association of coping strategies of situation control (a patient analyses the situation, plans and acts in order to control and to solve the problem) with an increase in the evaluation of some QoL aspects following treatment, and positive self-instruction (awarding oneself to the competences and power of control) leaded to higher satisfaction with marriage and partnership. If patients tend more often to actively detect and analyse the current situation, to plan remedies in order to improve the condition and to carry out an active response, these efforts result in an increase in QoL after treatment. Controlling the situation and giving oneself the value of being able to deal with a given situation in a competent way seems

\section{Tab. 4. Clinical factors and SVF 78 strategies as factors influencing value of life satisfaction questionnaire} (LSQ) components - multivariate linear regression analysis

\begin{tabular}{|c|c|c|c|c|}
\hline LSQ components: explanatory variables & beta $(95 \% \mathrm{Cl})$ & stand. beta & $\mathbf{P}$ & adjust. R-sq. \\
\hline \multicolumn{5}{|l|}{ health } \\
\hline $\begin{array}{l}\text { age (10-year change) } \\
\text { resignation (SVF 78) }\end{array}$ & $\begin{array}{c}0.318(0.049 ; 0.587) \\
-0.084(-0.112 ;-0.056)\end{array}$ & $\begin{array}{l}0.207 \\
-0.530\end{array}$ & $\begin{array}{r}0.021 \\
<0.001\end{array}$ & $31.5 \%$ \\
\hline \multicolumn{5}{|l|}{ employment } \\
\hline $\begin{array}{l}\text { situation control (SVF 78) } \\
\text { resignation (SVF 78) }\end{array}$ & $\begin{array}{l}-0.044(-0.077 ;-0.011) \\
-0.084(-0.119 ;-0.049)\end{array}$ & $\begin{array}{l}-0.273 \\
-0.493\end{array}$ & $\begin{array}{r}0.010 \\
<0.001\end{array}$ & $24.6 \%$ \\
\hline \multicolumn{5}{|l|}{ financial situation } \\
\hline resignation (SVF 78) & $-0.067(-0.097 ;-0.036)$ & -0.388 & $<0.001$ & $15.0 \%$ \\
\hline \multicolumn{5}{|l|}{ leisure time } \\
\hline $\begin{array}{l}\text { age (10-year change) } \\
\text { resignation (SVF 78) }\end{array}$ & $\begin{array}{l}-0.301(-0.586 ;-0.017) \\
-0.037(-0.066 ;-0.008)\end{array}$ & $\begin{array}{l}-0.221 \\
-0.267\end{array}$ & $\begin{array}{l}0.038 \\
0.013\end{array}$ & $10.1 \%$ \\
\hline \multicolumn{5}{|l|}{ marriage and partnership } \\
\hline positive self-instruction & $0.051(0.006 ; 0.096)$ & 0.286 & 0.027 & $6.6 \%$ \\
\hline \multicolumn{5}{|l|}{ children } \\
\hline resignation (SVF 78) & $-0.061(-0.097 ;-0.025)$ & -0.320 & 0.001 & $10.3 \%$ \\
\hline \multicolumn{5}{|l|}{ personality } \\
\hline $\begin{array}{l}\text { BMI (1-point change) } \\
\text { reaction control (SVF 78) } \\
\text { resignation (SVF 78) } \\
\text { self-accusation (SVF 78) }\end{array}$ & $\begin{array}{c}-0.069(-0.128 ;-0.011) \\
0.058(0.016 ; 0.100) \\
-0.038(-0.085 ; 0.009) \\
-0.050(-0.092 ;-0.008)\end{array}$ & $\begin{array}{l}-0.217 \\
0.263 \\
-0.204 \\
-0.290\end{array}$ & $\begin{array}{l}0.021 \\
0.007 \\
0.108 \\
0.020\end{array}$ & $29.5 \%$ \\
\hline \multicolumn{5}{|l|}{ sexuality } \\
\hline $\begin{array}{l}\text { diabetes mellitus in anamnesis } \\
\text { relapse } \\
\text { resignation (SVF 78) }\end{array}$ & $\begin{array}{c}1.315(0.110 ; 2.520) \\
-1.398(-2.619 ;-0.177) \\
-0.055(-0.108 ;-0.003)\end{array}$ & $\begin{array}{l}0.257 \\
-0.266 \\
-0.248\end{array}$ & $\begin{array}{l}0.033 \\
0.026 \\
0.040\end{array}$ & $17.8 \%$ \\
\hline \multicolumn{5}{|l|}{ friends and relatives } \\
\hline $\begin{array}{l}\text { reaction control (SVF 78) } \\
\text { resignation (SVF 78) }\end{array}$ & $\begin{array}{c}0.069(0.028 ; 0.110) \\
-0.053(-0.087 ;-0.019)\end{array}$ & $\begin{array}{l}0.326 \\
-0.305\end{array}$ & $\begin{array}{l}0.001 \\
0.002\end{array}$ & $21.7 \%$ \\
\hline \multicolumn{5}{|l|}{ housing } \\
\hline situation control (SVF 78) & $0.037(0.005 ; 0.068)$ & 0.215 & 0.024 & $4.6 \%$ \\
\hline \multicolumn{5}{|l|}{ total life satisfaction } \\
\hline $\begin{array}{l}\text { reaction control (SVF 78) } \\
\text { resignation (SVF 78) }\end{array}$ & $\begin{array}{c}0.046(0.004 ; 0.089) \\
-0.091(-0.127 ;-0.054)\end{array}$ & $\begin{array}{r}0.201 \\
-0.461\end{array}$ & $\begin{array}{r}0.034 \\
<0.001\end{array}$ & $28.1 \%$ \\
\hline
\end{tabular}

Components of SVF 78 were transformed on a scale of 0-100 and components of LSQ were transformed into stanine scores from 1 to 9 
to be very important for better coping with the illness and treatment. Active problem confrontation seems to be therefore an adaptive way in terms of OoL measures. This is in compliance with an earlier study which concluded that in cancer patients with either treatment intent (curative or palliative), active coping strategies and acceptance were beneficial in terms of QoL [22].

As the most influencing coping strategy appeared resignation (I tend to give up) negatively determined most of the scores of the all used QoL methods. Flight tendency (I only want to get out of this) and resignation are the most important coping strategies negatively influencing QoL. Self-accusation (tend to blame myself) was a significant predictor of bodily pain, lower vitality, emotional role functioning and in the first place lower mental health in univariate analysis. These three components are all part of overall negative strategy defined in SVF-78 method by authors. Negative coping strategies tend to increase experienced stress. We can carefully state the factor of emotional distress and resignation decrease almost the all QoL components in our study. As regards our interpretation of coping strategies as predictors of change of QoL following treatment, we based our work on the presumption that various coping strategies are variously adaptive, depending on a specific situation. Our results are supported by the prospective research study with a breast cancer cohort that showed a statistically significant link between "negative adjustment" (as assessed by a helplessness/hopelessness subscale, together with items regarding anxious preoccupation, fatalism, and avoidance) and increased risk of death and relapse after 5 and 10 years [23]. A consistent finding across several studies is that self-blame is associated with poorer adjustment among women with breast cancer [24-26].

Health care practitioners are encouraged to notice feelings of helplessness and hopelessness in their patients, to observe if patients seem lost in handling the difficult situation and tend to resign. They should be also attentive to a coping behaviour when patients seem to avoid the difficult situation, they pretend the difficult situation does not exist or if they tend to blame themselves that being ill is their fault. All of these negative coping strategies result in a poorer QoL after treatment and health care practitioner should recommend psychological and psychotherapeutical care as well. Coping strategies are mainly adopted and learnt throughout the life and therefore it is possible to change them and learn new ways of coping that are more adaptive.

On the other hand, health care practitioners can support patients to adopt more beneficial coping strategies such as realizing that a person has power over owns inner experience and can have behaviour under control. This strategy is associated with a higher general satisfaction in life and has a positive influence on interpersonal relationships. The coping strategy of fighting spirit, of not giving up, holding on while dealing with a severe illness turns out to be connected with a higher satisfaction in marriage which can further stabilize a person's life.

Greater age was connected to decreased satisfaction with leisure time, but on the contrary, patients of greater age had higher level of satisfaction with their health conditions, probably due to less expectations of older patients compared to younger in order to their health. Higher BMI negatively influenced the perception of personality. Being overweight or obese has a negative impact on QoL and its change over time in patients with breast cancer [27-29].

\section{Disease-related factors as predictors of QoL following treatment \\ Stage of disease and relapse}

Stratification according to clinical stages is of particular concern given that the stage of disease in itself can affect QoL [30]. Furthermore, breast cancer treatment is usually more intense and is stretched over longer periods of time in advanced stages of the disease. In our study, the only statistically significant clinical parameters in multivariate models were the fourth stage of the disease as a predictor of lower vitality and mental health in SF-36, and was significant multivariate factor for almost all FACT-B components. The relapse occurrence was linked to lower physical well-being and more additional concerns, and negatively influenced sexuality. An earlier stage of cancer was found to be a predictor for an improvement in physical health-related quality of life (HRQoL) [7]. Ivanauskiene [11] evaluated self-reported HRQoL within 1 year after breast cancer diagnosis in order to determine important factors associated with self-reported impaired HRQoL.

It is expectable that relapse and the fourth stage of the disease negatively influence the QoL. Even though it is a logical connection, we would like to emphasize this point by understanding that patents suffer not only on a physical plane but also their QoL is dropping enormously. While relapse negatively influences physical well-being and sexuality, the fourth stage of disease negatively influences the vitality and mental health.

\section{Limits of study}

Our study has its limitations. Our sample is relatively small. A longitudinal study with respect to baseline QoL prior to cancer treatment should be realised in future.

\section{Conclusions}

Our findings suggest a significant predictive power of disease-related factors (stage of disease, recurrence) and of patients' characteristics (BMI, age, certain coping strategies) with respect to QoL following treatment. The predictive potential of examined active control coping strategies as well as negative coping strategies for QoL has yet to be investigated more thoroughly.

\section{Sources of support}

The study was supported by the Czech Science Foundation as part of the project no. P407/12/0607. 


\section{Acknowledgements}

We deeply thank to our participants for their commitment to our research project.

\section{Competing interests}

All authors declare no financial competing interests in relation to the manuscript.

\section{References}

1. Ferrell BR, Dow KH, Grant N. Measurement of the quality of life in cancer survivors. Qual Life Res 1995; 4(6): 523-531.

2. Scieszka $M$, Zelinski $M$, Machalski $M$ et al. Quality of life in cancer patients treated by chemotherapy. Neoplasma 2000; 47(6): 396-399.

3. Hewitt ME, Herdman R, Holland JC et al. Meeting psychosocial needs of women with breast cancer. National Academies Press: Washington, D.C. 2004. ISBN 978-0-309-09129-9.

4. Dušek $L$, Mužík J, Kubásek $M$ et al. Epidemiologie zhoubných nádorů v České republice [online] 2007. Masarykova univerzita. Dostupné z WWW: http://www.svod.cz.

5. Dušek L, Mužík J, Malúšková D et al. Cancer incidence and mortality in the Czech Republic. Klin Onkol 2014; 27(6): 406-423. Dostupné z DOI: <http://dx.doi.org/10.14735/amko2014406>.

6. De Aguiar SS, Bergmann A, Mattos IE. Quality of life as a predictor of overall survival after breast cancer treatment. Qual Life Res 2014; 23(2): 627-637. Dostupné z DOI: <http://dx.doi.org/10.1007/ s11136-013-0476-8>.

7. Hyphantis T, Almyroudi A, Paika V et al. Anxiety, depression and defense mechanisms associated with treatment decisional preferences and quality of life in non-metastatic breast cancer: a 1-year prospective study. Psychooncology 2013; 22(11): 2470-2477. Dostupné z DOI: <http://dx.doi.org/10.1002/pon.3308>.

8. Lee MC, Bhati RS, von Rottenthaler EE et al. Therapy choices and quality of life in young breast cancer survivors: a short-term follow-up. Am J Surg 2013; 206(5): 625-631. Dostupné z DOI: <http://dx.doi. org/10.1016/j.amjsurg.2013.08.003>.

9. Lundh $\mathrm{MH}$, Lampic $\mathrm{C}$, Nordin $\mathrm{K}$ et al. Changes in health-related quality of life by occupational status among women diagnosed with breast cancer-a population-based cohort study. Psychooncology 2013; 22(10): 2321-2331. Dostupné z DOI: <http://dx.doi.org/10.1002/ pon.3285>.

10. von Blanckenburg $P$, Schuricht $F$, Albert US et al. Optimizing expectations to prevent side effects and enhance quality of life in breast cancer patients undergoing endocrine therapy: study protocol of a randomized controlled trial. BMC Cancer 2013; 13: 426. Dostupné z DOI: <http://dx.doi.org/10.1186/1471-2407-13-426>.

11. Ivanauskiene $R$, Padaiga $Z$, Simoliuniene $R$ et al. Well-being of newly diagnosed women with breast cancer: which factors matter more? Support Care Cancer 2014; 22(2): 519-526. Dostupné z DOI: $<$ http://dx.doi.org/10.1007/s00520-013-2005-2>.

12. Herndon JE, Kornblith AB, Holland JC et al. Effect of socioeconomic status as measured by education level on survival in breast cancer clinical trials. Psychooncology 2013; 22: 315-323. Dostupné z DOI: <http:// dx.doi.org/10.1002/pon.2094>.

13. Folkman S, Lazarus RS, Gruen RJ et al. Appraisal, coping, health status, and psychological symptoms. J Pers Soc Psychol 1986; 50(3): 571-579.

14. Zachariae R, Jensen AB, Pedersen $C$ et al. Repressive coping before and after diagnosis of breast cancer. Psychooncology 2004; 13(8): 547-561.

15. Beresford TP, Alfers J, Mangum L et al. Cancer survival probability as a function of ego defense (adaptive) mechanisms versus depressive symptoms. Psychosomatics 2006; 47(3): 247-253.
16. The NCI Dictionary of Cancer Terms. National Cancer Institute. Dostupné z WWW: <https://www.cancer.gov/publications/dictionaries/ cancer-terms>.

17. Cella DF, Tulsky DS, Gray G et al. The Functional Assessment of Cancer Therapy scale: development and validation of the general measure. J Clin Oncol 1993; 11(3): 570-579.

18. Ware JE, Sherbourne CD. The MOS 36-item short-form health survey (SF-36). I. Conceptual framework and item selection. Med Care 1992; 30(6): 473-483.

19. Sobotik Z. Our experience with the use of the preliminary Czech version of the US questionnaire on health (SF-36). Zdravotnictvi $v$ Ceske republice 1998; 1(1-2): 50-54.

20. Fahrenberg J, Myrtek M, Schumacher J et al. Questionnaire of Life Satisfaction. Testcentrum: Prague, Czech Republic 2001.

21. Janke W, Erdmann G. Strategies for stress coping. Testcentrum: Prague, Czech Republic 2003.

22. van Laarhoven HWM, Schilderman J, Bleijenberg G et al. Coping, Quality of Life, Depression, and Hopelessness in Cancer Patients in a Curative and Palliative, End-of-Life Care Setting. Cancer Nurs 2011; 34(4): 302-314. Dostupné z DOI: <http://dx.doi.org/10.1097/ NCC.0b013e3181f9a040>.

23. Watson M, Homewood J, Haviland J. Coping response and survival in breast cancer patients: A new analysis. Stress and Health 2012; 28(5): 376-380. Dostupné z DOI: <http://dx.doi.org/10.1002/smi.2459>.

24. Bennett K, Compas B, Beckjord E et al. Self-Blame and distress among women with newly diagnosed breast cancer. J Behav Med 2005; 28(4): 313-323. Dostupné z DOI: <ttp://dx.doi.org/10.1007/ s10865-005-9000-0>.

25. Friedman LC, Barber CR, Chang J et al. Self-blame, self-forgiveness, and spirituality in breast cancer survivors in a public sector setting. J Cancer Educ 2010; 25(3): 343-348. Dostupné z DOI: <http://dx.doi. org/10.1007/s13187-010-0048-3>.

26. Shapiro JP, McCue K, Heyman EN et al. Coping-related variables associated with individual differences in adjustment to cancer. J Psychosoc Oncol 2010; 28(1): 1-22. Dostupné z DOI: <http://dx.doi. org/10.1080/07347330903438883>.

27. Blanchard CM, Stein K, Courneya KS. Body Mass Index, Physical Activity, and Health-Related Quality of Life in Cancer Survivors. Med Sci Sports Exerc 2010; 42(4): 665-671. Dostupné z DOI: <http://dx.doi. org/10.1249/MSS.0b013e3181bdc685>.

28. Paxton RJ, Phillips KL, Jones LA et al. Associations among physical activity, body mass index, and health-related quality of life by race/ethnicity in a diverse sample of breast cancer survivors. Cancer 2012; 118(16): 4024-4031. Dostupné z DOI: <http://dx.doi.org/10.1002/ cncr.27389>.

29. Peuckmann V, Ekholm O, Rasmussen NK et al. Health-related quality of life in long-term breast cancer survivors: Nationwide survey in Denmark. Breast Cancer Res Treat 2007; 104(1): 39-46. Dostupné z DOI: $<$ http://dx.doi.org/10.1007/s10549-006-9386-6>.

30. Revannasiddaiah S, Rao N, Susheela SP et al. Quality of life assessment in breast cancer patients: The need for stratification of patients, and of the use of appropriate questionnaires. J Cancer Res Ther 2013; 9(4): 760. Dostupné z DOI: <http://dx.doi. org/10.4103/0973-1482.126496>.

\section{RNDr. Jiří Jarkovský, Ph.D. 四jarkovsky@iba.muni.cz}

Institute of Biostatistics and Analyses, Faculty of Medicine, Masaryk University, Brno, Czech Republic

\section{www.muni.cz}

Doručeno do redakce 27. 4. 2017

Prijato po recenzi 19. 6. 2017 